\title{
THE TREATMENT OF NEUROSYPHILIS WITH PENICILLIN*
}

\author{
BY \\ JAMES PURDON MARTIN \\ Physician to the National Hospital, Queen Square, London; Neurologist to the British Postgraduate \\ Medical School, London
}

Penicillin has excited the whole world. It has done for the common bacterial infections what the sulphonamides had done for meningococcal meningitis and quinine for malaria. But penicillin was an antibacterial remedy : it was not to be expected that it would be potent against the protozoal infection of syphilis. Moreover it was soon discovered that penicillin given intramuscularly did not find its way into the cerebrospinal fluid; it did not, it was said, pass the blood-brain barrier, and so it was inherently improbable that it would have much effect on syphilis of the nervous system. Moreover, we knew that nowhere did the spirochete become more strongly entrenched than in the brain. It was, therefore, right and natural that the first rumours that penicillin was in some degree effective in cases of neurosyphilis, and even in cases of general paralysis of the insane, should be received with a certain amount of incredulity, and this attitude is apparent in most of the reports on the trials of penicillin in neurosyphilis, for nearly all observers, finding some clinical improvement but little immediate change in the cerebrospinal fluid and blood, have gone on to treat their patients with malaria.

\section{Early Personal Experiences}

My own attitude at the beginning was the same. Just at the time when penicillin first became available for civilian use, a man of $\mathbf{5 0}$ suffering from taboparesis was admitted to the National Hospital, Queen Square, and came under my care. He was euphoric and fatuous, and had recently lost his position as accountant in a small firm. He was pursuing allotment gardening in a hypo-manic way, and had undertaken several allotments though he was a small, weak man. At home he was restless, irritable, obstinate, and sometimes tearful. He had some tremor of his lips and tongue and tremulous

\footnotetext{
* An address to the Society for the Study of Venereal Diseases, Jan. 24, 1948.
}

dysarthria, and he also had some tremor of his hands. His pupils were inactive to light, his kneejerks and ankle-jerks were absent, and his plantar reflexes were weakly extensor. His cerebrospinal fluid showed typical paretic characteristics, and his blood Wassermann was strongly positive.

I decided to try the effect of penicillin in this case. The reports which had come from America had at first suggested that over a million units might be necessary for a case of neurosyphilis, but by the time treatment was started on this patient it was being said that even two million units were required Fortunately we were able to obtain this amount? and the patient was given a course of two million units in injections of 20,000 units at a time, every three hours. When the course was finished he had certainly made some clinical improvement. He was less restless, a little less expansive, able to concentrate better and to remember better. Physically he was less tremulous, but the other physical signs were unchanged. To our disappointment his cerebrospinal fluid, examined ten days after the completion of his course of penicillin, showed practically no change. The Americans, of course, had had a long start of us, and the few reports which were then available indicated that penicillin was inadequate for dementia paralytica and that it was necessary to use malaria as well. Faced with the lack of serological improvement in my patient and with this information from America, it seemed obviously the appropriate course to proceed with malarial therapy, and this was done without waste of time. I did nevertheless say, being impressed with the clinical improvement, that it would be a pity to cure the patient with penicillin and then, for the sake of confirming the cure, to kill him with malaria. This, in fact, was almost what happened. The patient, at the time of his fifth rigor, passed into a semicomatose state with low muttering delirium, and the malaria was hurriedly arrested. Nevertheless he 
remained first in a state of semi-coma and muttering, and later for nearly a fortnight in a condition of profound dementia with lapses into delirium. In the end, however, he made a very good recovery, although I do not think his mental state has ever been quite so good as it was before the malaria started.

This was by no means my first contretemps with malaria, but it was a new lesson. Meanwhile, Dr. E. A. Carmichael had started one of his patients, a case of frank G.P.I., on penicillin, and he invited me to observe the case with him. This man, when his course of three million units was finished, also showed clinical improvement. His cerebrospinal fluid still showed paretic abnormalities, and his blood Wassermann was still strongly positive. Nevertheless we decided that we were going to treat the patient and not the cerebrospinal fluid; and clinically we saw no call for immediate further treatment, and certainly no justification for submitting him to the dangers from which the first patient had so narrowly escaped. After a short period of observation in the hospital, during which he continued to improve, he was allowed to go home. His improvement continued, and after nine months he was very much better clinically.

Since then I have treated thirty or forty cases and none of them has had malaria, so that what I present to you now is a series of cases treated either with penicillin alone, or with penicillin supplemented only by the usual chemicals. I confess that I have always had a strong dislike of malarial therapy and have used it with great reluctance.

\section{The Present Series}

The series consists of twenty-four cases which I had treated at the National Hospital, Queen Square, London, before the end of September last. I know this number is puny compared to the numbers in some of the American series, but this will not surprise those who are aware of the extent of the decline of neurosyphilis in this country. Even in the American reports the number of cases described as treated by penicillin alone is not very large, most of the series consisting of cases treated by combined methods.

The cases hitherto reported in England are few. Smith (1947) reported seven of general paralysis treated by penicillin alone and observed for periods up to thirteen months. Lescher and Richards (1947) described ten cases of neurosyphilis of different types treated with penicillin alone and other cases treated by combined methods. Nicol and Whelen have referred to the immediate effects in fourteen cases treated with penicillin alone, and in a larger number with a combined method.
In my series there were eight patients who presented with mental symptoms, and they all had "paretic" spinal fluids; one other patient whose presenting symptom was hemi-paresis, due evidently to a vascular lesion, also had a "paretic" fluid ; five patients were typical cases of tabes, and two others were predominantly cases of optic atrophy, while nine patients were instances of different varieties of meningo-vascular syphilis.

\section{Group I : Dementia Paralytica}

Under this heading I include all cases with dementia and with "paretic" changes in the cerebrospinal fluid. The group consists of eight cases (nos. 1, 3, 7, 9, 14, 18, 20, 21,.in chronological order), the first five of which were treated more than a year ago. Case 14 was due to congenital infection; Case 18 has been lost sight of ; in Case 21 the mental symptoms were relatively mild and the dominant clinical features were tabetic. The clinical histories of these cases are given below, and their cerebrospinal fluid and blood findings are shown in Table $\mathbf{l}$.

Case 1.-A man aged 52 years, first seen on Feb: 20 , 1945, had been dismissed from his post as a secretaryaccountant; and his wife said he had been "changed mentally" for about a year, and was now a very different man. His memory was bad and he lost things; he was apt to cry; he was unable to do his income-tax return and unable to understand things that formerly he would have dealt with easily ; he was easily fatigued and complained of pains in his legs. On examination he laughed in a silly way and had a tremulous dysarthria, but he made no mistakes in talking and was able to subtract 7 successively from 100 without error, though his cerebration was rather slow. His tongue and hands were tremulous and he had Argyll Robertson pupils. His knee jerks and ankle jerks were absent, and his plantar reflexes flexor. When he was admitted to hospital his cerebrospinal fluid showed paretic changes and the Wassermann reaction was strongly positive in his blood.

He was given 2 mega units (2M) of penicillin, after which he showed some improvement in his memory and emotional state, but his cerebrospinal fluid showed little change. He was subsequently infected with malaria. During the fifth rigor he became gravely ill and passed into a state of muttering delirium, from which he recovered gradually in the course of a fortnight. After this his mental state was possibly not quite so good, but in the course of a few months he improved again. His wife said he was much better than before his treatment, but he was still talkative and easily amused.

In March, 1947, two years after the original treatment, the wife thought he was not so well and he was readmitted to hospital. He had no tremor and his plantar responses were flexor as before ; his cerebrospinal fluid was normal except for the Lange curve which was still of the paretic type, and the Wassermann reaction was negative in his blood. Although no deterioration in his mental 
TABLE I

CHANGES IN "PARETIC" CEREBROSPINAL FLUIDS

\begin{tabular}{|c|c|c|c|c|c|c|c|c|c|c|c|}
\hline \multirow{3}{*}{ Case } & \multirow{3}{*}{$\begin{array}{l}\text { Time of } \\
\text { Treatment }\end{array}$} & \multirow{3}{*}{ Pen. } & \multicolumn{6}{|c|}{ Cerebrospinal Fluid } & \multirow{2}{*}{\multicolumn{2}{|c|}{ Blood }} & \multirow{3}{*}{ Other Treatment } \\
\hline & & & \multirow{2}{*}{$\begin{array}{l}\text { Cells } \\
\text { per } \\
\text { c.mm. }\end{array}$} & \multirow{2}{*}{$\begin{array}{l}\text { Pro- } \\
\text { tein } \\
\text { mg. \% }\end{array}$} & \multicolumn{2}{|c|}{ Globulin } & \multirow{2}{*}{ W.R. } & \multirow{2}{*}{ Lange } & & & \\
\hline & & & & & N.A. & Pandy & & & W.R. & Kahn & \\
\hline 1 & $\begin{array}{l}\text { Before pen. } \\
\text { After : } \\
1-2 \text { weeks } \\
\text { (5 rigors) } \\
2 \text { months } \\
5 \text { ", } \\
24 \text { ", } \\
30 \text {, }\end{array}$ & $2 \mathrm{M}$ & $\begin{array}{r}13 \\
4 \\
0 \\
0 \\
3 \\
0 \\
\end{array}$ & $\begin{array}{l}60 \\
50 \\
60 \\
70 \\
45 \\
55 \\
\end{array}$ & $\begin{array}{l}+ \\
\pm \\
+ \\
+ \\
+ \\
+\end{array}$ & $\begin{array}{l}+ \\
+ \\
+ \\
+ \\
+ \\
\pm\end{array}$ & $\begin{array}{c}4444 \\
4420 \\
4444 \\
4442 \\
- \\
- \\
\end{array}$ & $\begin{array}{l}4555554321 \\
1223322221 \\
1223443321 \\
4555554210 \\
5554432110 \\
5554321000 \\
\end{array}$ & $\begin{array}{c}4444 \\
4442 \\
4444 \\
4442 \\
\ldots \\
- \\
\end{array}$ & $\begin{array}{l}. \\
\therefore \\
.\end{array}$ & $\begin{array}{l}\cdots \\
\cdots \\
\cdots \\
\cdots \\
\cdots\end{array}$ \\
\hline$\overline{3}$ & $\begin{array}{l}\text { Before pen. } \\
\text { After : } \\
1-2 \text { weeks } \\
9 \text { months } \\
12 \quad, \\
22 \quad, \\
27\end{array}$ & $3 \mathrm{M}$ & $\begin{array}{l}3 \\
1 \\
\cdots \\
\cdots \\
\cdots\end{array}$ & $\begin{array}{l}70 \\
60 \\
\text { Not } \\
\cdots\end{array}$ & \begin{tabular}{|c|}
+ \\
\pm \\
$\ldots$ \\
known \\
$\cdots$
\end{tabular} & \begin{tabular}{|c|}
+ \\
+ \\
$\ldots$ \\
$:$ patie \\
$\ldots$ \\
$\ldots$
\end{tabular} & \begin{tabular}{|c|}
4420 \\
3200 \\
$\ldots$ \\
well \\
$\ldots$ \\
$\ldots$
\end{tabular} & \begin{tabular}{|l}
3333432211 \\
5555554310 \\
clinically
\end{tabular} & $\begin{array}{c}4431 \\
4420 \\
- \\
3100 \\
- \\
-\end{array}$ & $\begin{array}{l}\cdots \\
+ \\
\ddot{+} \\
\cdots \\
\cdots\end{array}$ & $\begin{array}{l}\text { Mist. pot. iod. and } \\
\text { mercury for } 10 \\
\text { days before pen. } \\
\ldots \\
\ldots \\
.\end{array}$ \\
\hline 7 & \begin{tabular}{|l} 
Before pen. \\
After : \\
1-2 weeks \\
2 months \\
$5 \quad$, \\
$6_{2}^{1} \quad$, \\
$10 \quad$,
\end{tabular} & $3 \mathrm{M}$ & $\begin{array}{r}12 \\
15 \\
4 \\
0 \\
3 \\
3\end{array}$ & $\begin{array}{r}90 \\
120 \\
100 \\
70 \\
65 \\
40\end{array}$ & $\begin{array}{l}+ \\
\cdots \\
\cdots \\
- \\
- \\
\cdots \\
-\end{array}$ & $\begin{array}{l}+ \\
\cdots \\
\ddot{ \pm} \\
\pm \\
-\end{array}$ & $\begin{array}{c}++++ \\
++++ \\
++++ \\
4200 \\
- \\
-\end{array}$ & $\begin{array}{l}55200000 \\
43320000 \\
43210000 \\
0000000000 \\
0000000000 \\
0000000000 \\
0000000000 \\
0001100000\end{array}$ & \begin{tabular}{|c|}
$\cdots$ \\
$\cdots$ \\
4442 \\
4443 \\
4444 \\
4420 \\
3100 \\
\end{tabular} & $\begin{array}{l}\ddot{*} \\
\ddot{+} \\
+ \\
+\end{array}$ & $\begin{array}{l}\text { Mist. pot. iod. and } \\
\text { mercury for 1 } \\
\text { month. } \\
\text { NAB plus bis- } \\
\text { muth. } \\
\text { NAB plus bis- } \\
\text { muth. } \\
\text { Pot. iod. and mer- } \\
\text { cury for 1 month. } \\
\text { NAB plus bismuth. }\end{array}$ \\
\hline$\overline{9}$ & $\begin{array}{l}\text { Before pen. } \\
\text { Afier: } \\
1-2 \text { weeks } \\
7 \text { months }\end{array}$ & $4 \mathrm{M}$ & $\begin{array}{r}38 \\
16 \\
3\end{array}$ & $\begin{array}{l}80 \\
80 \\
60\end{array}$ & $\begin{array}{l}+ \\
+ \\
+\end{array}$ & $\begin{array}{l}- \\
+ \\
+\end{array}$ & $\begin{array}{c}4444 \\
4322 \\
4200 \\
- \\
- \\
-\end{array}$ & \begin{tabular}{|c|}
4544322100 \\
3443210000 \\
4433211000 \\
\\
4554321100 \\
2233321100 \\
$\ldots$
\end{tabular} & $\begin{array}{l}4444 \\
3321 \\
4200 \\
\\
2000 \\
4200 \\
3100\end{array}$ & $\begin{array}{l}+ \\
\pm \\
+\end{array}$ & $\begin{array}{l}\text { Mist. pot. iod. for } \\
3 \text { months. } \\
\text { Bismuth } \times \quad 8 \text {; } \\
\text { Mist. pot. iod. for } \\
3 \text { months. } \\
\ldots \\
\text { Mist pot. iod. for } \\
3 \text { months. } \\
\end{array}$ \\
\hline 14 & $\begin{array}{l}\text { Before pen. } \\
\text { After: } \\
1-2 \text { weeks } \\
12 \text { months }\end{array}$ & $3 \cdot 6 \mathrm{M}$ & $\begin{array}{l}3 \\
3\end{array}$ & $\begin{array}{l}25 \\
25\end{array}$ & \pm & \pm & $\stackrel{4420}{-}$ & \begin{tabular}{|l|}
5555432100 \\
\\
2321100000 \\
3433210000
\end{tabular} & 4310 & + & $\begin{array}{l}11 \text { courses arsenic, } \\
\text { iod., and bismuth } \\
\text { in previous } 4 \\
\text { years. } \\
\text { Mist. pot. iod. and } \\
\text { mercury at present. }\end{array}$ \\
\hline$\overline{17}$ & $\begin{array}{l}\text { Before pen. } \\
\text { After: } \\
4 \text { months } \\
9 \text {.., }\end{array}$ & $4 \cdot 6 \mathrm{M}$ & $\begin{array}{r}24 \\
4 \\
1\end{array}$ & $\begin{array}{l}40 \\
30 \\
25 \\
\end{array}$ & $\begin{array}{l}+ \\
- \\
-\end{array}$ & $\begin{array}{l}+ \\
\overline{ \pm}\end{array}$ & $\begin{array}{r}4442 \\
2 \overline{0} \\
\end{array}$ & \begin{tabular}{|l|}
4555432110 \\
\\
4432100000 \\
1223221000 \\
\end{tabular} & $\begin{array}{l}4444 \\
4442 \\
4420 \\
\end{array}$ & .. & $\begin{array}{l}\text { Mist. pot. iod. for } \\
2 \text { months. } \\
\text { Course NAB. }\end{array}$ \\
\hline 20 & $\begin{array}{l}\text { Before pen. } \\
\text { After: } \\
3 \text { months } \\
9\end{array}$ & $5 \mathrm{M}$ & $\begin{array}{l}6 \\
2 \\
0\end{array}$ & $\begin{array}{l}40 \\
40 \\
35\end{array}$ & $\begin{array}{l}- \\
- \\
-\end{array}$ & $\begin{array}{l} \pm \\
\pm \\
\end{array}$ & $\begin{array}{r}4420 \\
4 \\
- \\
-\end{array}$ & \begin{tabular}{|l|}
5554432100 \\
4543210000 \\
0000000000
\end{tabular} & - & $\begin{array}{l}- \\
- \\
\ldots\end{array}$ & $\begin{array}{c}10 \text { rigors. Sulfosin } \\
1934 . \\
\ldots \\
\ldots\end{array}$ \\
\hline 21 & $\begin{array}{l}\text { Before pen. } \\
\text { After: } \\
6 \text { months } \\
7\end{array}$ & $3 \mathrm{M}$ & $\begin{array}{r}296 \\
5\end{array}$ & $\begin{array}{l}85 \\
45\end{array}$ & $\begin{array}{l}- \\
\pm\end{array}$ & $\begin{array}{l}+ \\
\pm\end{array}$ & $\begin{array}{l}4200 \\
- \\
- \\
\end{array}$ & $\begin{array}{l}5555432100 \\
0112211000\end{array}$ & 4200 & .. & 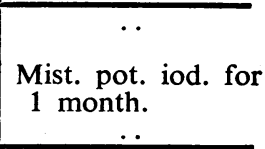 \\
\hline
\end{tabular}


condition was apparent to us, he was given further penicillin. He continues to work two or three allotments, and acts as secretary for the local allotment holders. He has lost his tremor and talks and acts rationally, although he is still easily amused and apt to be garrulous.

Case 3.-A man, aged 58 years, first seen in May, 1945, for four months had had tremor of his hands, weakness of the legs, and depression. He sometimes became confused so that, for instance, he was unable to find his way home. He had difficulty in concentrating on his work as a time-keeper. On examination he was found to have a poor memory, slurred speech, tremor of his tongue, lips, and hands, brisk knee and ankle jerks, extensor plantar responses, slight ataxia, and positive Romberg sign. The Wassermann reaction was positive in his blood and cerebrospinal fluid. He was given 3 mega units of penicillin.

When he was seen after nine months he had returned to work as a time-keeper. He said that in the evenings he read books, but he was unable to remember the name of the last book he had read. His wife said that he seemed very well. He had a tremor of his tongue, lips, and hands, weakly extensor plantar responses, and weakly positive Romberg sign. The Wassermann reaction was negative in his blood. Since then he has refused to attend hospital because he feels so well, and he is able to write a letter to this effect in firm handwriting and competent English.

Case 7.-A woman, aged 60 years, was first seen by me in May, 1946, at another hospital, to which her daughter had brought her because she complained of headache and slowness. Her cerebration was slow and she had some tremor of her lips and tongue, but otherwise few abnormal physical signs. She was put on the admission list, but was brought up again by her daughter a fortnight later because her mental state was so much worse, and also because she had fallen down once or twice. On admission to hospital her cerebration was very slow and she answered only in monosyllables. Her speech was tremulous and she had a marked tremor of her lips and tongue and slight tremor of her hands. She was somnolent and sometimes incontinent of urine. After 3 mega units of penicillin her headache had quite gone, she was brighter, and her cerebration was quicker, but her answers were still very brief. Her tremor was less and she soon ceased to be incontinent. After that her mental state steadily improved, but as there was little improvement in her cerebrospinal fluid and blood a further course of penicillin ( 3 mega units) was given after two months. Gradual improvement continued, and four months later she was admitted to the National Hospital for re-investigation. She was then able to give a fairly good account of herself, but she was quite unable to perform any of the usual psychological tests, such as subtracting 7 successively from 100 . Her pupils did not react very briskly to light and she had a little-tremor in her tongue and speech, but otherwise no abnormal physical signs. In the last two years she has improved greatly, and for nearly a year now she has run her house and done her own shopping. She answers ordinary questions normally, but with specific intelligence tests she makes a poor score.

Case 9.-A married woman of 42 years was first seen in June, 1946, when she complained of attacks of severe pain beneath her right shoulder blade during the previous eight months. Examination showed some slight left ptosis, slight pupillary abnormalities, and slightly increased reflexes in her left leg. Simple tests showed considerable impairment of intelligence and memory, and her emotional state was unstable. It subsequently came out that for some time past she had been very difficult to live with because of her irritability. During the next eighteen months she had two courses of 4 mega units of penicillin, one course of eight injections of bismuth, and three courses of potassium iodide by mouth. At the end of this time she was symptom-free. "I am feeling better than I have for years." The Wassermann reaction was negative in her cerebrospinal fluid and weakly positive in her blood. Her physical signs remained the same. Psychological examination showed generalized deterioration amounting to 24 per cent. loss by Wechsler's method.

Case 14.-A woman of 27 years first attended the hospital in March, 1943. She gave one year's history of unsteadiness, giddy attacks, and slurred speech. On examination she was found to be an apathetic girl with absent knee and ankle jerks and extensor plantar reflexes. Between that time and January, 1947, she had many courses of arsenicals and bismuth, but her Wassermann reaction was still strongly positive in the blood and cerebrospinal fluid. Her mother said then that she had been deteriorating recently. On examination at this time she was found to be apathetic, negativistic, and of very low intelligence : her kneejerks and ankle-jerks were absent and her plantar reflexes were extensor. She was given a course of 4.5 mega units of penicillin, followed by mercury and iodides by mouth. Now (January, 1948) she is considerably improved. She is more alert and is working in a factory where she is contented. She answers simple questions normally, but her speech is slightly tremulous. Her ataxia is less severe, but otherwise her physical signs are substantially the same. The Wassermann reaction is weakly positive in her blood and negative in her cerebrospinal fluid.

Case 20.-A man, aged 59 years, was first seen in 1933. He had ten rigors induced by "Sulfosin," and between then and June, 1947, he had several courses of neoarsphenamine. Until recently he had carried on a skilled occupation, but in the last year or two he had been in and out of several jobs and was depressed. Before admission he had been acting strangely and had been extremely forgetful, irritable, tearful, and obstinate. On examination then he had impaired intelligence, absent ankle jerks, postural loss in his feet, and extensor plantar responses. The Wassermann reaction was negative in his blood but positive in his cerebrospinal fluid, and the Lange curve was " paretic." After 5 mega units (5M) of penicillin his mental state showed little 
change for about two months, and then improved rapidly, and after four months he returned to work, though at a less skilled occupation. He has continued to improve clinically and after nine months his cerebrospinal fluid is normal.

Case 21.-A man aged 45 years, when first seen in June, 1947, had tabetic physical signs and intellectual deterioration. Since treatment he has less severe lightning pains but objectively remains substantially the same. He has returned to his normal work.

\section{GROUP II : TABES}

Of the five cases in this group (nos. $6,8,10,15$, 19), three had received previous treatment. I have lost sight of Case 19. None of the patients concerned had a very actively syphilitic cerebrospinal fluid, and their fluids and bloods have become normal or almost normal with relative ease. Tabes being a slow degenerative disease, not much positive clinical improvement can be expected and it will take a long time to determine whether or not the disease is arrested. The clinical histories are outlined below, and the cerebrospinal fluid and blood findings are shown in Table II.
Case 6.-A woman, aged 52 years, was first seen in April, 1946, when she complained of numbness in her legs and feet and loss of balance ; she had had treatment abroad for tabes. Stabbing pains had begun in 1944. In April, 1945, it was found that the Wassermann reaction was strongly positive in the blood and the cerebrospinal fluid, and the latter contained 20 lymphocytes per c.mm. She was treated at that time with tryparsamide and bismuth. On admission to the National Hospital in April, 1946, she had absent knee and ankle jerks, and Romberg's sign was positive. Her pupils were equal and acted moderately well to light, but her optic discs were pale, especially the right one. She had some constriction of the right visual field, but visual acuity was normal, and in fact better in the right eye than in the left. She was given 3 mega units of penicillin, after which her physical signs showed no change but she was free from shooting pains. She was unable to take potassium iodide and mercury, and was subsequently given another course of penicillin and also a course of bismuth injections. Her cerebrospinal fluid and blood had become normal, and when she left England again in June, 1947, her physical signs and vision were unchanged.

Case 8.-A man, aged 58 years, when first seen in 1942 was a typical tabetic. His condition has remained

TABLE II

TABES · DORSALIS

\begin{tabular}{|c|c|c|c|c|c|c|c|c|c|c|c|}
\hline \multirow{3}{*}{ Case } & \multirow{3}{*}{$\begin{array}{l}\text { Time of } \\
\text { Treatment }\end{array}$} & \multirow{3}{*}{ Pen. } & \multicolumn{6}{|c|}{ Cerebrospinal Fluid } & \multirow{2}{*}{\multicolumn{2}{|c|}{ Blood }} & \multirow{3}{*}{ Other Treatment } \\
\hline & & & \multirow{2}{*}{$\begin{array}{l}\text { Cells } \\
\text { per } \\
\text { c.mm. }\end{array}$} & \multirow{2}{*}{$\begin{array}{l}\text { Pro- } \\
\text { tein } \\
\text { mg. } \%\end{array}$} & \multicolumn{2}{|c|}{ Globulin } & \multirow{2}{*}{ W.R. } & \multirow{2}{*}{ Lange } & & & \\
\hline & & & & & N.A. & Pandy & & & W.R. & Kahn & \\
\hline 6 & $\begin{array}{l}\text { Before pen. } \\
\text { After: } \\
2 \text { months } \\
5 \text {, } \\
12 \quad,\end{array}$ & $3 \cdot 5 \mathrm{M}$ & $\begin{array}{l}0 \\
2 \\
\cdots \\
\cdots\end{array}$ & $\begin{array}{l}65 \\
50 \\
\cdots \\
\cdots\end{array}$ & $\begin{array}{l}- \\
- \\
\cdots \\
\cdots\end{array}$ & $\begin{array}{l} \pm \\
\pm \\
\cdots \\
\cdots\end{array}$ & $\begin{array}{l}- \\
- \\
\cdots \\
\cdots\end{array}$ & $\begin{array}{c}0001110000 \\
\text { No change } \\
\ldots \\
\cdots\end{array}$ & $\begin{array}{c}4200 \\
3100 \\
- \\
-\end{array}$ & $\begin{array}{l}+ \\
\pm \\
\pm\end{array}$ & $\begin{array}{c}\text { Tryparsamide. } \\
\text {.. } \\
\text {. } \\
\text {. }\end{array}$ \\
\hline 8 & $\begin{array}{l}\text { Before pen. } \\
\text { After: } \\
1-2 \text { weeks } \\
12 \text {. months }\end{array}$ & $3 \mathbf{M}$ & $\begin{array}{l}6 \\
4\end{array}$ & $\begin{array}{l}80 \\
90 \\
50\end{array}$ & \pm & \pm & $\begin{array}{r}4442 \\
-v e \\
- \text { ve }\end{array}$ & $\begin{array}{l}0000122210 \\
0011110000 \\
\text { No change }\end{array}$ & $\begin{array}{c}4420 \\
4200 \\
-\end{array}$ & $\ddot{-}$ & $\begin{array}{c}\text { Arsenic and bis- } \\
\text { muth in several } \\
\text { courses. } \\
\ldots \\
\ldots\end{array}$ \\
\hline 10 & $\begin{array}{l}\text { Before pen. } \\
\text { After: } \\
1-2 \text { weeks } \\
15 \text { months }\end{array}$ & $5 \mathrm{M}$ & $\begin{array}{r}38 \\
12 \\
1\end{array}$ & $\begin{array}{l}35 \\
\\
35 \\
40\end{array}$ & $\begin{array}{l} \pm \\
- \\
-\end{array}$ & $\begin{array}{l} \pm \\
\pm \\
-\end{array}$ & $\begin{array}{c}4442 \\
4420 \\
-\end{array}$ & $\begin{array}{l}0122110000 \\
\text { No change } \\
0122100000\end{array}$ & $\begin{array}{l}4444 \\
4444 \\
2100\end{array}$ & $\begin{array}{l}++ \\
+ \\
+\end{array}$ & $\begin{array}{l}\text { Pot. iod. ten days } \\
\text { before penicillin. } \\
\quad . \\
\text { Course of NAB } \\
\text { and pot. iod. for } \\
3 \text { months. }\end{array}$ \\
\hline 15 & $\begin{array}{l}\text { Before pen. } \\
\text { After: } \\
9 \text { months }\end{array}$ & $4 \cdot 5 \mathrm{M}$ & $\begin{array}{l}0 \\
\cdots\end{array}$ & $\begin{array}{l}25 \\
\cdots\end{array}$ & $\begin{array}{l}- \\
\cdots\end{array}$ & $\begin{array}{l}- \\
\cdots\end{array}$ & $\begin{array}{l}- \\
\ldots\end{array}$ & $\begin{array}{c}\text { No change } \\
\text {.. }\end{array}$ & $\begin{array}{l}4420 \\
2000\end{array}$ & $\begin{array}{l}+ \\
+\end{array}$ & $\begin{array}{l}\text {. } \\
\text { NAB and bismuth ; } \\
\text { Mist. pot. iod. and } \\
\text { mercury. }\end{array}$ \\
\hline
\end{tabular}


objectively unchanged after penicillin but he thinks he can walk more steadily than before.

Case 10.-A married woman, aged 54 years, when first seen in August, 1946, was a mild tabetic with old choroido-retinitis and a recent third nerve palsy. Her ocular palsy had recovered and she was symptom-free after penicillin, her tabetic signs remaining unchanged.

Case 15.-A man, aged 69 years, when first seen in January, 1947, had classical tabetic signs and pale optic discs, and he complained of intermittent digestive disturbances.' After treatment he said he felt much better ; his objective signs were unchanged.

Case 19.-A man, aged 45 years, was first seen in August, 1941, and diagnosed as tabetic. His physical condition remained much the same after penicillin. Since treatment he has said that he feels " extremely well."

\section{Group III : Optic Atrophy}

Three patients (nos. 5, 11, and 23) presented with loss of vision. The greatest interest attaches to the first of these, a man who when first seen was blind in his right eye, and complaining of diminishing sight in the left. Both discs were paper-white and there seemed little chance of saving any sight. With special precautions at the start, and preliminary potassium iodide and mercury, he was given 5 mega units of penicillin, and excision of the stellate sympathetic ganglion was performed on the left side with the idea of increasing the blood supply to the left optic nerve. No further diminution of sight was observed, and in the course of some months his acuity of vision in the left eye, which was at first $6 / 12$, recovered to $6 / 9$ and later to $6 / 6$, and at present it is a little better than $6 / 6$. The visual field has remained full. In the other eye, too, there was a little recovery of sight, which enables him to see hand movements in a part of the field. In cases of optic atrophy I have seen improvement of vision followed subsequently by deterioration, and so I cannot be confident about the outlook in this case, but it is now over two years since the first treatment, and therefore one can be hopeful. In any case it is evident that in this case penicillin had an effective and prompt action.

The second of these cases is also noteworthy, because it is the only case in the series in which symptoms continued to progress after a course of penicillin.

The state of the cerebrospinal fluid and blood of these patients is given in Table III. Case 23, though included in this group for convenience, is of a different type from the other two.

Case 5.-A man aged 52 years, already referred to, was first seen in October, 1945 . In 1914 he had had a penile sore for which he received treatment with mercury for one year. In 1944 he noticed that his sight was beginning to fail, and seven weeks before admission he found that he was unable to see at all with his right eye. On examination both discs showed primary optic atrophy (V.R., P.L., V.L., 6/12). He had Argyll Robertson pupils and some hypalgesia over the face, chest, and ulnar side of the forearms, and on the shins.

TABLE III

OPTIC ATROPHY

\begin{tabular}{|c|c|c|c|c|c|c|c|c|c|c|c|}
\hline \multirow{3}{*}{ Case } & \multirow{3}{*}{$\begin{array}{l}\text { Time of } \\
\text { Treatment }\end{array}$} & \multirow{3}{*}{ Pen. } & \multicolumn{6}{|c|}{ Cerebrospinal Fluid } & \multirow{2}{*}{\multicolumn{2}{|c|}{ Blood }} & \multirow{3}{*}{ Other Treatment } \\
\hline & & & \multirow{2}{*}{$\begin{array}{l}\text { Cells } \\
\text { per } \\
\text { c. } \mathrm{mm} .\end{array}$} & \multirow{2}{*}{$\begin{array}{c}\text { Pro- } \\
\text { tein } \\
\text { mg. } \%\end{array}$} & \multicolumn{2}{|c|}{ Globulin } & \multirow{2}{*}{-W.R. } & \multirow{2}{*}{ Lange } & & & \\
\hline & & & & & N.A. & Pandy & & & W.R. & Kahn & \\
\hline 5 & $\begin{array}{l}\text { Before pen. } \\
\text { After: } \\
6 \text { weeks } \\
7 \text { months } \\
12 \\
26\end{array}$ & $\begin{array}{l}4 \mathrm{M} \\
5 \mathrm{M}\end{array}$ & $\begin{array}{l}8 \\
2 \\
4\end{array}$ & $\begin{array}{l}75 \\
50 \\
70 \\
\cdots \\
\cdots\end{array}$ & $\begin{array}{l}\dot{-} \\
\pm \\
+ \\
.\end{array}$ & $\begin{array}{l} \pm \\
\pm \\
+ \\
\because \\
\cdots\end{array}$ & $\begin{array}{l}- \\
- \\
- \\
\cdots \\
\cdots\end{array}$ & $\begin{array}{c}1122100000 \\
1122210000 \\
\text { No change } \\
\ldots \\
\ldots\end{array}$ & $\begin{array}{l}4443 \\
4444 \\
4200 \\
4420 \\
4420\end{array}$ & $\begin{array}{l}+ \\
\cdots \\
+ \\
+ \\
+\end{array}$ & $\begin{array}{l}\text { Pot. iod. for } 10 \\
\text { days. } \\
\text { NAB plus mercury } \\
\text { inunctions. } \\
\text { Mercury inunctions } \\
\text { for } 2 \text { months. } \\
\text { Bismuth, } 2 \text { courses; } \\
\text { Mist. pot. iod. and } \\
\text { mercury. }\end{array}$ \\
\hline 11 & $\begin{array}{l}\text { Before pen. } \\
\text { After: } \\
1-2 \text { weeks } \\
9 \text { months }\end{array}$ & $\begin{array}{l}4 \mathrm{M} \\
3 \mathrm{M}\end{array}$ & $\begin{array}{r}44 \\
36 \\
1\end{array}$ & $\begin{array}{l}25 \\
35 \\
20\end{array}$ & $\begin{array}{l}- \\
\overline{-}\end{array}$ & $\begin{array}{l}- \\
-\end{array}$ & $\begin{array}{l}4420 \\
4321 \\
-\end{array}$ & $\begin{array}{l}0011110000 \\
\text { No change } \\
\text { No change }\end{array}$ & $\begin{array}{l}4420 \\
2100 \\
2000\end{array}$ & $\ddot{-}$ & $\begin{array}{l}\qquad \\
\text { Mercury } \\
\text { pot. iod. } \\
\text { mercury. }\end{array}$ \\
\hline
\end{tabular}


The Wassermann reaction was positive in his blood and cerebrospinal fluid. He has had two courses of 5 mega units and one course of 4 mega units of penicillin. His left stellate ganglion was excised in November, 1945. He has also had arsenicals, bismuth, mercury by inunction, and potassium iodide by mouth. In December, 1947, his acuity was 6/6. His left field is full. The Wassermann reaction is still positive in his blood but negative in his cerebrospinal fluid.

Case 11.-A man, aged 49 years, was first seen in August, 1946, when he complained of progressive dimness of vision during the last eighteen months and sharp rheumatic pains in the legs for the last ten years. On examination his vision in each eye was 6/24. Both discs showed primary optic atrophy. He had Argyll Robertson pupils and slight ptosis. His left knee jerk was diminished and his ankle jerks absent. He had impaired pain sense on th: ulnar side of his forearms and on his legs. His menory was poor as judged by simple tests. The Wassermann reaction was positive in blood and cerebrospinal fluid. He had 4 mega units of penicillin. Six months later his vision, right and left, was $6 / 36$, and he had bilateral extensor plantar responses. In May, 1946, he had a further 3 mega units of penicillin followed by mercury inunction. His vision is still 6/36 in either eye. He has shown no further intellectual deterioration. The Wassermann reaction is negative in blood and cerebrospinal fluid.

Case 23.-A man, aged 33 years, admitted in September, 1947, had a primary sore in December, 1946, for which he received no treatment. He was admitted to the National Hospital in September, 1947, with three months' history of progressive dimness of vision in both eyes. On examination his vision was $3 / 60$ in either eye, there was a ring of pigment on his left lens, he had some vitreous haze, the discs were blurred, and he had bilateral central scotomata for red and green. The Wassermann reaction was positive in his blood and cerebrospinal fluid. He received two courses of 5 mega units of penicillin, followed by potassium iodide by mouth. In November his vision, right and left, was $6 / 12$, and the Wassermann reaction in his blood was less strongly positive.

\section{Group IV: Meningo-Vascular Syphilis}

Of the eight cases of meningo-vascular syphilis, three (nos. 4, 16, and 17) presented vascular symptoms. Case 16 had generalized vascular disease with high blood pressure and was a type of case in which probably little improvement could be expected. Case 17 had paretic changes in the cerebrospinal fluid which are shown in Table $\mathbf{I}$; clinically and serologically she has improved greatly.

Of the remaining cases in this group the first two were of subacute spinal syphilis, and these have shown only moderate improvement. The other three are all women with cerebral syphilis, two of whom had papillœdema and all of whom have improved considerably after treatment. The records of their cerebrospinal fluid and blood findings are given in Table IV.

Case 4.-A man, aged 57 years, was first seen in June, 1945, when he complained of increasing deafness during the previous five years. Six months before admission he had had a subarachnoid hæmorrhage from which he made a good recovery, and subsequently a positive Wassermann reaction was found in the cerebrospinal fluid. He also gave a history of having had syphilis as a young man. On examination he was found to have moderate nerve deafness, his right pupil was small, irregular, and did not react to light, his plantar reflexes were extensor, and he had a positive Romberg sign. The Wassermann reaction was then negative in his blood and cerebrospinal fluid. However, he was given 3 mega units of penicillin and afterwards potassium iodide. Now his cerebration is quicker and he says he is feeling more alert, but examination shows no change in his objective signs.

Case 16.-A man, aged 63 years, was first seen in April, 1947. During the previous six years his wife had noticed progressive deterioration of his intellect, character, and habits. He had become bankrupt, dirty, objectionable, and slovenly. Six weeks before he had had a sudden weakness of his right side, which was improving. When seen he was unkempt, incapable of giving a history, and with no insight into his condition. His blood pressure was $250 / 153 \mathrm{~mm}$. $\mathrm{Hg}$. His speech was slurred, and he had Argyll Robertson pupils and bilateral extensor plantar responses. The Wassermann reaction was strongly positive in his blood and positive in his cerebrospinal fluid. He was given a course of 5 mega units of penicillin. He was then discharged from hospital, but within a few days was admitted to another where he still remains. His condition has improved a little. The Wassermann reaction in his blood is positive.

Case 17.-A married woman, aged 42 years, when first seen in April, 1947, complained of weakness of her legs for one year and sudden onset of left-sided weakness fourteen days before. This latter symptom had improved. On examination she had the signs of a mild left hemiparesis. She also had Argyll Robertson pupils. Except for the left supinator jerk, her tendon jerks were absent. Her cerebrospinal fluid showed "paretic" changes, and her blood Wassermann reaction was strongly positive (see Table I). She was given a course of 4.5 mega units of penicillin followed by potassium iodide by mouth, and later, twelve injections of neoarsphenamine. Her hemiparesis recovered almost completely. She is now symptom-free except that she cannot run. Psychological examination shows no appreciable deterioration. The Wassermann reaction of her blood is still positive, but that of her cerebrospinal fluid is negative.

Case 2.-A woman, aged 51 years, was first seen in April, 1945. For two years she had had difficulty in 
walking because her legs were stiff and she was unsteady, and for one week she had had blurring of the vision of her left eye. Examination showed her to have slight left ptosis, nystagmus on lateral and vertical deviation of her eyes, slight left facial weakness, marked deafness, intention tremor of her hands and feet, spastic weakness of her legs, and an absent left ankle jerk. Her plantar reflexes were indefinite. She received 3 mega units of penicillin, followed by potassium iodide. In August, 1946, she was readmitted. The Wassermann reaction was positive in her blood but negative in her cerebrospinal fluid. She was given a further 6 mega units of penicillin. In January, 1948, she was walking poorly and on a widened base and generally used a stick; she still had postural loss in her feet and equivocal plantar reflexes. Her mental condition was improved: she had difficulty in concentrating but was able to memorize five, sometimes six digits, and could subtract 7's from 100 slowly and with some mistakes. The Wassermann reaction was positive in her blood but negative in her cerebrospinal fluid.

Case 13.-A woman, aged 52 years, was first seen in August, 1946. She complained of headache for six weeks, and double vision, vomiting, and dizziness for five weeks. On examination she had papillodema, left external rectus palsy, right facial palsy, absent abdominal reflexes, and an ataxic gait. She was given 5 mega units of penicillin. One month later the papillodema was only very slight and her gait was much improved. In October, 1946, she had an attack of aphasia and weakness of the right arm and leg, which improved gradually. When seen late in 1947 she had very slight residual weakness of the right side of her face, but was otherwise apparently normal. The Wassermann reaction was weakly positive in her blood but negative in cerebrospinal fluid.

Case 22.-A woman, aged 45 years, when seen in September, 1947, had intellectual deterioration and epilepsy. Since treatment she has had no further epileptic attacks, and her mental condition is no worse and if anything better, but detailed tests have not been carried out.

Case 24.-A married woman, aged 27 years, was first seen in September, 1947. For several months she had suffered from headache and progressive dimness of vision. On examination her vision, right and left, was $6 / 36$ and she had very severe papillœdema. The

TABLE IV

MENINGO-VASCULAR SYPHILIS

\begin{tabular}{|c|c|c|c|c|c|c|c|c|c|c|c|}
\hline \multirow{3}{*}{ Case } & \multirow{3}{*}{$\begin{array}{l}\text { Time of } \\
\text { Treatment }\end{array}$} & \multirow{3}{*}{ Pen. } & \multicolumn{6}{|c|}{ Cerebrospinal Fluid } & \multirow{2}{*}{\multicolumn{2}{|c|}{ Blood }} & \multirow{3}{*}{ Other Treatment } \\
\hline & & & \multirow{2}{*}{$\begin{array}{l}\text { Cells } \\
\text { per } \\
\text { c.mm. }\end{array}$} & \multirow{2}{*}{$\begin{array}{c}\text { Pro- } \\
\text { tein } \\
\text { mg. } \%\end{array}$} & \multicolumn{2}{|c|}{ Globulin } & \multirow{2}{*}{ W.R. } & \multirow{2}{*}{ Lange } & & & \\
\hline & & & & & N.A. & Pandy & & & W.R. & Kahn & \\
\hline 2 & $\begin{array}{l}\text { Before pen. } \\
\text { After: } \\
3 \text { weeks } \\
16 \text { months } \\
17 \text { ", } \\
32 \text { ", }\end{array}$ & $\begin{array}{l}3 \mathrm{M} \\
6 \mathrm{M}\end{array}$ & $\begin{array}{r}17 \\
0 \\
0 \\
0 \\
1\end{array}$ & $\begin{array}{r}280 \\
60 \\
35 \\
35 \\
40\end{array}$ & $\begin{array}{l}+ \\
+ \\
- \\
-\end{array}$ & $\begin{array}{l}+ \\
+ \\
\pm \\
\pm \\
-\end{array}$ & $\begin{array}{l}4444 \\
4420 \\
\overline{4200} \\
-\end{array}$ & $\begin{array}{l}2223333321 \\
223322211 \\
\text { No change } \\
0012111000 \\
0112210000\end{array}$ & $\begin{array}{l}4444 \\
4444 \\
4200 \\
4200 \\
4310\end{array}$ & $\begin{array}{l}+ \\
\ddot{+} \\
\ddot{+}\end{array}$ & $\begin{array}{l}\text {.. } \\
\text { Mist. pot. iod. } \\
\text { Mist. pot. iod. } \\
\text {.. }\end{array}$ \\
\hline 12 & $\begin{array}{l}\text { Before pen. } \\
\text { After : } \\
2 \text { weeks } \\
10 \text { months } \\
16 \quad "\end{array}$ & $\begin{array}{l}5 \mathrm{M} \\
5 \mathrm{M}\end{array}$ & $\begin{array}{r}49 \\
10 \\
2 \\
\cdots\end{array}$ & $\begin{array}{l}50 \\
45 \\
45 \\
.\end{array}$ & $\begin{array}{l}+ \\
- \\
\pm \\
\cdots\end{array}$ & $\begin{array}{l}+ \\
\pm \\
\pm \\
.\end{array}$ & $\begin{array}{l}4420 \\
- \\
- \\
\cdots\end{array}$ & $\begin{array}{c}0012211000 \\
0012110000 \\
0011100000 \\
\ldots\end{array}$ & $\begin{array}{c}4444 \\
4444 \\
4200 \\
-\end{array}$ & $\begin{array}{l}+ \\
+ \\
\cdots \\
\cdots\end{array}$ & $\begin{array}{c}\cdots \\
\ldots \\
\text { NAB course. } \\
\cdots\end{array}$ \\
\hline 13 & $\begin{array}{l}\text { Before pen. } \\
\text { After : } \\
1 \text { week } \\
6 \text { months } \\
15 \quad "\end{array}$ & $5 \mathrm{M}$ & $\begin{array}{r}30 \\
75 \\
0 \\
\cdots\end{array}$ & $\begin{array}{l}65 \\
35 \\
35 \\
\cdots\end{array}$ & $\begin{array}{l}+ \\
+ \\
+\end{array}$ & $\begin{array}{l}+ \\
+ \\
- \\
\cdots\end{array}$ & $\begin{array}{l}++ \\
++ \\
- \\
\cdots\end{array}$ & $\begin{array}{c}\text { No change } \\
\text { No change } \\
\text { No change } \\
. .\end{array}$ & $\begin{array}{l}3200 \\
3100\end{array}$ & $\begin{array}{l}\cdots \\
\cdots \\
\cdots\end{array}$ & $\begin{array}{l}\cdots \\
\cdots\end{array}$ \\
\hline 22 & $\begin{array}{l}\text { Before pen. } \\
\text { After: } \\
10 \text { weeks }\end{array}$ & $\begin{array}{l}5 \mathrm{M} \\
5 \mathrm{M} \\
\end{array}$ & $\begin{array}{r}98 \\
0\end{array}$ & $\begin{array}{l}80 \\
55\end{array}$ & $\begin{array}{l}+ \\
-\end{array}$ & $\begin{array}{l}+ \\
\pm\end{array}$ & $\begin{array}{l}4444 \\
4200\end{array}$ & $\begin{array}{l}\text { No change } \\
0112211000\end{array}$ & $\begin{array}{l}4444 \\
4444\end{array}$ & $\begin{array}{l}+ \\
+\end{array}$ & . \\
\hline 24 & $\begin{array}{l}\text { Before pen. } \\
\text { After: } \\
1 \text { month }\end{array}$ & $5 \mathrm{M}$ & $\begin{array}{r}23 \\
0\end{array}$ & $\begin{array}{l}70 \\
40\end{array}$ & - & $\begin{array}{l} \pm \\
-\end{array}$ & $\begin{array}{c}4420 \\
-\end{array}$ & $\begin{array}{l}0011100000 \\
0012211000\end{array}$ & $\begin{array}{l}4444 \\
2000\end{array}$ & $\begin{array}{l}+ \\
. .\end{array}$ & $\begin{array}{l}\cdots \\
\cdots\end{array}$ \\
\hline
\end{tabular}


Wassermann reaction was positive in blood and cerebrospinal fluid. She was given a course of 5 mega units of penicillin in January of this year. The swelling of her discs has entirely subsided and she is symptom-free.

\section{Results in General}

Looking back over these twenty-four cases we may consider the apparent effects of the treatment in more general terms - the clinical effects, the effects on the cerebrospinal fluid, and the effects on the blood.

Clinical Effects.-In most cases it is evident that the progress of the symptoms has been arrested; we may exclude from consideration in this respect the cases of tabes-since in the nature of things they are not likely to show much objective change in a short time-and also the cases which have been lost sight of. That leaves eighteen cases in which clinical progress can be assessed. In Case 11, visual impairment continued to progress after the first treatment with penicillin was given, but in all the other cases the progress of symptoms has been arrested, and in nearly all of them the patient has made positive recovery. Arrest of symptoms is all that can be expected clinically in the first instance from even the most effective treatment, and any positive recovery that occurs afterwards depends on the state of the nervous tissue after the disease process has been stopped ; its degree is not a measure of the effectiveness of the treatment. Whether the arrest of the clinical progress of the disease will be permanent is impossible to say yet, but so far there have been no relapses and no deaths as far as I know.

Effects on the Cerebrospinal Fluid.-The effects on the cerebrospinal fluid and blood form the best criterion of the probable permanence of the arrest of the disease and of its eradication. In most instances the Wassermann reaction in the cerebrospinal fluid has become negative in about a year. It is not known when it became negative in Case 1, but it was found negative at the end of two years. The number of cells in the fluid usually becomes normal quickly and has always been within normal limits by the end of two months. The total protein content becomes normal more slowly, and frequently shows an increase immediately after trèatment, which may last for one or two months. This is probably to be regarded as an indication of the reaction that has gone on in the tissues, and particularly in the cerebrum, and it is in keeping with what occurs in other diseases. The tests for excess globulin usually become normal about the same time as the total protein. The colloidal gold reaction shows the most persistent change in the cerebrospinal fluid, and in Cases 1 and 14 it is still of the paretic type after thirty months and twelve months respectively, when all other features of the fluid are approximately normal. As is well known, this also happens after malarial treatment and the significance of this persistence is difficult to determine. In most instances, if the fluid is otherwise " inactive," the reaction dies out in the course of some years, and it seems unlikely that an active colloidal gold reaction is to be regarded as any sign of activity of the disease. In any case, patients with positive colloidal gold reactions should be watched. With the exception of the colloidal gold reactions, and occasionally of the total protein, all the cerebrospinal fluids in my series have returned to a normal state within about twelve months. The sequence of changes in the cerebrospinal fluid after penicillin therapy is thus exactly the same as that which follows successful treatment with malaria, and we may recall Dattner's insistence that a fluid which has become negative after malaria never becomes positive again.

Effects on the Blood.-It seemed at first that penicillin did not have much influence on the Wassermann reaction of the blood, but as time has gone on the reaction in the blood has become negative in a number of patients who have had no treatment except penicillin, and in some other patients it now shows a decided weakening. . In cases in which neoarsphenamine and bismuth were given in addition, the state of the blood is no better than in the others. In general, the blood reactions in the series as a whole seem now as good as would have been obtained by any other method of treatment, but the delay in the correction of the blood Wassermann after that of the cerebrospinal fluid has become normal is difficult to understand. A similar delay is known to occur after malarial treatment, but after penicillin it is more striking, possibly because other changes occur more quickly than after malaria (Table V).

The combined effects of the treatment on the clinical state and on the states of the cerebrospinal fluid and blood all indicate that treatment with penicillin is effective and adequate and provide good grounds for hope that the results will be permanent.

\section{Dose and Method of Administration}

In all cases penicillin has been given by the intramuscular route only. Sodium penicillin was used for most of the cases, and in recent times the crystalline form whenever obtainable.

In the early days the total amount given in each course was two million Oxford units ( 2 mega units). This was soon increased to 3 and then 4 , and for the last two years the course has been standardized at 5 mega units. 
For the first day the doses are small, but thereafter 60,000 units are given every three hours, making nearly half a million units daily, and this rate of administration is continued until a total of approximately 5 mega units has been reached. During the first day, as a precaution against Jarisch-Herxheimer reactions, much smaller doses are given. These may be either of the order of 15,000 units three times in the course of the day, or recently 10,000 units hourly, with orders to the Sister to stop administration if the patient seems upset or makes any complaint. No untoward reactions of any kind have been seen.

An elderly woman suffering from tabes, who had previously been under my care and who visited me again recently, received penicillin treatment in her own home, not under my instructions. She said that she was given 1 mega unit in a single injection

TABLE $\mathrm{V}$

BLOOD WASSERMANN REACTION BEFORE AND AFTER PENICILLIN

\begin{tabular}{|c|c|c|c|c|c|c|}
\hline \multirow{2}{*}{ Case } & \multirow{2}{*}{$\begin{array}{l}\text { Blood } \\
\text { W.R. } \\
\text { before } \\
\text { Pen. }\end{array}$} & \multicolumn{4}{|c|}{ Treatment } & \multirow{2}{*}{$\begin{array}{c}\text { Blood } \\
\text { W.R. } \\
\text { Jan., } 1948\end{array}$} \\
\hline & & \multicolumn{3}{|c|}{ Pen. } & Other & \\
\hline 1 & 4444 & & $2 \mathrm{M}$ & $5 \mathrm{M}$ & .. & - \\
\hline 2 & 4444 & & $3 \mathbf{M}$ & $6 \mathrm{M}$ & $\cdots$ & 4310 \\
\hline 3 & 4431 & & & $3 \mathbf{M}$ & $\ldots$ & - \\
\hline 4 & - & & & $3 \mathrm{M}$ & & - \\
\hline 5 & 4443 & $5 \mathrm{M}$ & $4 \mathrm{M}$ & $5 \mathrm{M}$ & $\begin{array}{l}\text { NAB plus } \\
\text { bismuth, } \\
\text { mercury, } \\
\text { pot. iod. }\end{array}$ & 4200 \\
\hline 6 & 4200 & 3 & $3 \cdot 5 \mathrm{M}$ & $4 \mathrm{M}$ & Bismuth & - \\
\hline 7 & . & $3 \mathrm{M}$ & $4 \mathrm{M}$ & $5 \mathrm{M}$ & $\begin{array}{l}\text { NAB plus } \\
\text { bismuth, } \\
\text { pot. iod., } \\
\text { and mer- } \\
\text { cury }\end{array}$ & 4420 \\
\hline $\begin{array}{l}8 \\
9\end{array}$ & $\begin{array}{l}4420 \\
4444\end{array}$ & & $4 \mathrm{M}$ & $\begin{array}{l}3 \mathrm{M} \\
4 \mathrm{M}\end{array}$ & $\begin{array}{l}\text { B is muth, } \\
\text { Pot. iod. }\end{array}$ & $3 \overline{100}$ \\
\hline 10 & 4444 & & & $5 \mathrm{M}$ & $\cdots$ & 2100 \\
\hline 11 & 4420 & & $4 \mathrm{M}$ & $3 \mathrm{M}$ & $\ldots$ & - \\
\hline 12 & 4444 & & $5 \mathrm{M}$ & $5 \mathrm{M}$ & . & - \\
\hline 13 & iisis & & & $5 \mathrm{M}$ & & 3100 \\
\hline 14 & 4444 & & & $4 \cdot 6 \mathrm{M}$ & $\begin{array}{l}\text { Pot. iod. } \\
\text { and mer- } \\
\text { cury }\end{array}$ & .4310 \\
\hline 15 & 4420 & & & $4.6 \mathrm{M}$ & . & 2000 \\
\hline 16 & 4444 & & & $5 \mathrm{M}$ & & Unknown \\
\hline 17 & 4444 & & & $4 \cdot 6 \mathrm{M}$ & $\mathrm{NAB} \times 12$ & 4420 \\
\hline 18 & 4444 & & & $5 \mathrm{M}$ & $\cdots$ & Unknown \\
\hline $\begin{array}{l}19 \\
20\end{array}$ & $\begin{array}{l}4432 \\
-\end{array}$ & & & $\begin{array}{l}5 M \\
5 M\end{array}$ & . & Unknown \\
\hline 21 & 4200 & & $5 \mathrm{M}$ & $.5 \mathrm{M}$ & Pot. iod. & - \\
\hline 22 & 4444 & & $5 \mathrm{M}$ & $5 \mathrm{M}$ & $\therefore$ & $\frac{4444-}{(25 y}$ \\
\hline $\begin{array}{l}23 \\
24\end{array}$ & $\begin{array}{l}4444 \\
4444\end{array}$ & & & $\begin{array}{l}5 \mathrm{M} \\
5 \mathrm{M}\end{array}$ & $\begin{array}{l}\ldots \\
\ldots\end{array}$ & $\begin{array}{l}4420 \\
2000\end{array}$ \\
\hline & & & & & & \\
\hline
\end{tabular}

each day for seven days. She herself obtained the penicillin from the chemist and had charge of it in her house, so she knew the amount. After the first dose she had intense pains in her legs, and after the second she had first terrible pains and then numbness in her legs, and pains in her back and headache : the remaining doses each excited some pains and she dreaded the daily injection, but she went through with the course. The numbness passed off but she says she does not walk as well since this experience. This is the only first-hand information I have had of a possible Herxheimer reaction to penicillin, but such reactions have been referred to by various American workers.

In the early days we had not appreciated the importance of time as a factor in the improvement of the cerebrospinal fluid and blood; and, dealing with such inexorable conditions as paresis and optic atrophy, we could not afford to take any additional risks. One patient with dementia paralytica had three courses within eight months, another with optic atrophy three courses within twelve months. In the light of subsequent experience such intensity of treatment seems a little lavish. It is true that the results were very good in both cases, but probably not sufficient time was given for the full effects of the first course to show themselves, and the same results might perhaps now be obtained with more economy of treatment. Gammon and others (1946) suggest that the right time for repetition of the course is after four months, but my experience leads me to think that by that time the whole influence of the first course is not yet apparent either clinically or in the cerebrospinal fluid and blood, and if the clinical condition is satisfactory longer intervals may be allowed.

In several different cases the cerebrospinal fluid has been examined for evidence of the presence of penicillin, but in no instance has it shown any inhibiting effect on the standard test cultures.

\section{Adjuncts to Penicillin}

Of the adjuncts to penicillin the first and most important is time : 5 mega units plus six or twelve months does far more than 5 mega units alone, and in all my more recent cases I have been content to allow intervals of this order before re-examination of the cerebrospinal fluid and consideration of the call for further therapy. Most observers have not given time its opportunity before going on to malaria, but those who have done so describe very good results.

The second most important adjunct is probably more penicillin. However, until we know the full value of time after the first course it is impossible to say just how valuable a second course is. Effects 
that were attributed to repetition of the penicillin in my Cases 5 and 7 may well have been due in fact to time.' In Case 11, however, in which visual deterioration due to optic atrophy was still progressing six months after the first course, a second course of penicillin seemed to arrest it.

As other adjuncts I have used neoarsphenamine, bismuth, mercurial inunction, and a mercury and iodide mixture in different cases. Mercury and iodide possibly exert a better effect than anything else on the more subacute or chronic pathological formations in meningo-vascular syphilis, and if this is so they have a special place in the treatment. Tryparsamide I have not yet used as an adjuvant to penicillin, and until we can assess more exactly the effects of penicillin itself it would be impossible to determine the value of the combination; but it obviously may have a place.

\section{Comparison with Malarial Therapy}

To revert to the more active of our cases-those with mental symptoms and "paretic" fluids and those with optic atrophy-we have to consider the two important questions : (1) Are the results as good as those that would have been obtained with malaria ? and, (2) Could the results be improved by giving malaria as well ?

In times past eight at least and probably ten of these patients (including those with optic atrophy) would have received malarial treatment. Would the results have been any better? My own experience suggests that they would not have been as good, and actually in the last half dozen cases treated by my colleagues with malaria at Queen Square, the serological results to date are not as good as those of the.cases treated with penicillin alone. We must bear in mind both the limited effectiveness of malaria and the dangers and difficulties of the treatment. Malaria alone is effective in the sense that it arrests the disease in general paralysis in about 55 per cent. of cases, and the remaining cases gradually progress so that 40 per cent. of all the patients treated die within five years. The mortality associated with the period of treatment and the subsequent months is about 10 per cent. The results are considerably improved by combining tryparsamide with malaria, but even with the combination the disease is not arrested in all cases. With penicillin therapy the risks and difficulties of treatment are obviously very much less, and if the results obtained are at all comparable, as they undoubtedly are, the advantages are conspicuous. I do not overlook the fact that my own small series contains no case of acute general paralysis of the insane, but Nicol and Whelen (1947) in this country, and also Smith (1947), have reported great clinical improvements in such cases with penicillin alone.

American reports are mixed, but Callaway and his associates (1946) considered that treatment with penicillin was more effective than with malaria, and Rose and others (1946) concluded that there was little to choose between the results obtained with penicillin alone and those with malaria followed by tryparsamide. Dattner and others (1947) consider that penicillin when given in adequate doses is at least as effective in the treatment of neurosyphilis as combined fever and specific chemical therapies. A fuller account of the American reports has recently been given by Worster Drought (1947), and there is now also a short review by Nicol (1948).

But there is the further question-would still better results be obtained by giving malaria as well ? For practical purposes the question must be : would any improvement commensurate with the risk be obtained by giving malaria as well ? In the last resort this question may be settled by practical experience, and from the reports that have been published of comparable series of cases treated by different methods it is evident that there is no great difference in the results. In a series described by Rose and Solomon (1947) there was no material difference in the percentages of clinical improvement whether the patients were treated with penicillin and malaria, penicillin and the fever cabinet, or penicillin alone. From the report of a smaller series described by Lescher and Richards (1947) in this country, it is also evident that the results were very similar, although the observers concluded that the best clinical results seemed to have been achieved with malaria and penicillin, closely followed by those obtained with penicillin alone.

There are two general aims in treatment. The first is to obtain arrest of the disease as rapidly as is consistent with safety, and the second is to ensure its permanence. If a rapid arrest can be obtained by any means, additional treatment for the same purpose is useless, and if it involves risk it is certainly unjustified. Treatment cannot restore the cerebral tissue: it can only arrest the disease. Arrest as rapidly as is consistent with safety is the only first requirement. From what I have seen it seems that the syphilitic processes are inhibited by penicillin before malaria could even come into operation, although further experience is necessary to show whether that inhibition is sufficiently complete in all kinds of cases.

I am sure it is fallacious to say that clinical recovery occurs more quickly or more completely after this or that method of treatment, provided only that the treatment is effective, that is, that it exterminates the causal organism of the disease. 
After any sufficiently effective treatment the extent of clinical recovery depends on the amount of the cerebral tissue that is capable of recovery and that is not a function of the treatment but of the viable cerebral tissue. Similarly the period of clinical recovery is the time required for the recovery of such cerebral tissue as is capable of restored activity. The final results cannot vary between one effective method of treatment and another, provided the treatments themselves are inocuous and reasonably prompt in their actions, and if an effective treatment has once been given no greater or quicker improvement can possibly be obtained by a multiplication of therapies. The practical results that have been obtained are in general agreement with this conclusion.

Our only criterion for the permanence of cures is the serological reactions. After the disease is arrested these take time to become normal ; if the cerebrospinal fluid is of the "inactive" type after three months, and normal, apart from the colloidol gold reaction, within two years, we may be satisfied. Such results are obtainable with penicillin as with malaria, and there seems no reason why they should not be as permanent. Though serological relapses must be watched for, they are likely to be few.

\section{Conclusions}

As a result of my observations I draw the following tentative conclusions-and I emphasize that they are tentative because longer observation is necessary.
1. Penicillin is sufficient in most cases of neurosyphilis. Whether it is adequate for the more acute cases of general paralysis of the insane the experience by this series does not show.

2. If, with the possible exception of such cases, the patient can be kept under observation after treatment and penicillin repeated if necessary, malaria will seldom be called for, and the risk of it will seldom be justified.

3. Even if penicillin does not render malaria unnecessary, it is a potent weapon and will make us much less dependent on malaria, and risks which were necessary before need not now be taken.

I wish to express my thanks to Dr. J. N. Cumings for examination of the cerebrospinal fluids and bloods, and to Dr. J. S. Prichard for his help in following up the cases described.

\section{REFERENCES}

Callaway, J. L., and others. (1946). Amer. J. Syph., 30, 110.

Dattner, B., Thomas, E. W., and Wexler, G. (1944).

"The Management of Neuro-syphilis." New York. (1947). Arch. Neurol. Psychiat., Chicago, 57, 270.

Gammon, G. D., Stokes, J. H., and others. (1946). Ann. intern. Med., 25, 412.

Lescher, F. G., and Richards, H. R. M. (1947). Brit. med.J., 2, 565.

Nicol, W. D., and Whelen, M. (1947). Lancet, 1, 559.

- (1946). Brit. J. vener. Dis., 22, 112.

- (1948). Postgrad. med.J., 24, 25.

Rose, A. S., and others. (1946). Arch. Neurol. Psychiat., Chicago, 55, 428.

, and Solomon, H. C. (1947). J. Amer. med. Ass., 133,5 .

Smith, R. H. F. (1947). Lancet, 1, 665. ,

Worster Drought, C. (1947). Brit. med.J. 2, 559.

\section{DISCUSSION ON THE TREATMENT OF NEUROSYPHILIS WITH PENICILLIN}

DR. W. D. Nicol said there was no doubt that malaria was not devoid of considerable risks. It was true that at Horton Hospital the mortality rate had been as high as 8 per cent.; nevertheless it was found that in the latent neurosyphilitic cases, of which quite a considerable number had now been treated, there was no mortality. Therefore it did appear with the patients in whom the more active process of disease was going on, as in general paralysis of the insane, that the risk was very much higher. It was quite clear that, for this most active disease process, treatment by malaria should be supplemented by something else, and at Horton Hospital they had based their conclusions on the work done with malaria and tryparsamide. He himself did not like tryparsamide, and Dr. Martin had not used it in any of the cases he had described that afternoon. How far penicillin might supersede malaria therapy remained to be seen. It would certainly entail very much less clinical anxiety and trouble; but were they going to find that penicillin would be sufficient from the point of view of therapy? Dr. Martin, quite rightly, was cautious in his conclusions. They would have to wait several years to know the complete answer. Penicillin had been used to a considerable extent at Horton Hospital, where his colleague was getting together data on a hundred cases that had been under observation for one year and more.

He waş glad to hear that Dr. Martin advocated confining oneself to one form of therapy and seeing what it would do before starting another. So far as optic atrophy or one of these major disasters was concerned, one had to be very quick about treatment and not waste time, but with other clinical manifestations one should be very careful to see what a particular form of therapy was capable of doing and what effect it was likely to have before abandoning it for something else. 